\title{
Seasonal Statistical Analysis on the Quality of Underwater Supplies in South-Eastern Romania
}

\author{
GABRIEL MURARIU1,2*, MIHAELA TIMOFTI1,2*, IONELIA SAVINUTA ${ }^{1,2}$, ADRIAN MURARIU3*, CATALINA ITICESCU ${ }^{1.2}$, \\ LUCIAN GEROGESCU1.2, MARIAN TUDOR ${ }^{4}$, GEORGE DANUT MOCANU 5 \\ 'Dunarea de J os University of Galati, Faculty of Sciences and Environment, 111 Domneasca Str., 800201, Galati, Romania \\ 2Dunarea de J os University of Galati, Faculty of Sciences and Environment, 111 Domneasca Str., 800201, Galati, Romania \\ ${ }^{3}$ Department of Physics, Imperial College London, Kensington, London SW7 2AZ, UK \\ ${ }^{4}$ The Danube Delta National Institute for Research and Development, 165 Babadag Str, 820112, Tulcea, Romania \\ ${ }^{5}$ Dunarea de J os University of Galati, Faculty of Physical Education and Sport, 63 Garii Str., 800003, Galati, Romania
}

In this paper are presented preliminary results of seasonal statistical approach on monitoring of a series of drilled water well corresponding on a surface of about a quarter of Galati County which has a total area of 4,466 square $\mathrm{km}$. In order to offer an adequate picture of the status of this natural resource we started a monthly monitoring program that cover approximatively 20 monitoring points for two years. The study is an extension of previous research, with a total of 21 sampling points.

Keywords: monitoring, water quality, drilled water well, Principal Components Analysis

In 2014, at the Cornell University was designed and is in developing stage a water quality monitoring program that includes both groundwater monitoring and surface water monitoring. The data from this periodic monitoring can be used to identify issues that may need corrective actions [1]. In addition, water quality monitoring of irrigation sources (particularly water supply wells and storage lakes) provides valuable agronomic information that can inform nutrient and liming programs. A water quality monitoring plan should identify appropriate sampling locations, frequency, and monitoring parameters (Florescu et al., 2011, Timofti et al., 2016, Popa et al., 2018).

For Romania, an investigation for the water quality monitoring process could be welcome (Florescu et al., 2011, Timofti et al., 2016, Popa et al., 2018).

In this paper are presented preliminary results of an ambitious plan of monitoring a series of drilled water well corresponding on a surface of about a quarter of Galati County which has a total area of 4,466 square $\mathrm{km}$.

The started program covers about 20 monitoring points for a series of two years, in order to succeed in reaching a fine representation of the well water quality in this area.

This study will be submitted to the local authorities and to the county institutions in order to offer an adequate picture of the status of this natural resource.

\section{Experimental part}

The sampling of water probe that were used in this study was made on a route with a length of $56 \mathrm{~km}$ located in Galai County [3]. The starting point was the Serbanesti village followed by: Hanu Conachi, Tudor Vladimirescu, Vames, Piscu, Independenta, Branistea, Sendreni, Movileni, the end point being located in Filesti and Barbosi, districts of Galati. All settlements are located on county road DN 25. In table 1 we presented the GPS coordinates references of sampling points.

In figure 1 is presented a conventional map of Galati County and the sampling points for studied water. In table 1 the GPS coordinates references of sampling points are presented.

It should be mentioned that in each locality two sampling points have been settled with minimum distance of $500 \mathrm{~m}$
Table 1

GPS COORDINATES REFERENCES OF SAMPLING POINTS

\begin{tabular}{|c|l|c|c|}
\hline Crt. No. & Sampling Point & Latitude & Longitude \\
\hline 1 & Şerbăneşti & 45.616589 & 27.536738 \\
\hline 2 & Şerbăneşti 1 & 45.609174 & 27.535923 \\
\hline 3 & Hanu Conachi & 45.592795 & 27.581027 \\
\hline 4 & Hanu Conachi 1 & 45.586481 & 27.601551 \\
\hline 5 & T. Vladimirescu & 45.570478 & 27.635969 \\
\hline 6 & T. Vladimirescu 1 & 45.560143 & 27.654755 \\
\hline 7 & Vameş & 45.534815 & 27.700846 \\
\hline 8 & Vameş 1 & 45.531966 & 27.706189 \\
\hline 9 & Piscu & 45.514474 & 27.717091 \\
\hline 10 & Piscu 1 & 45.500527 & 27.728763 \\
\hline 11 & Independența & 45.476533 & 27.754726 \\
\hline 12 & Independenţa 1 & 45.473705 & 27.762237 \\
\hline 13 & Braniştea & 45.433937 & 27.833433 \\
\hline 14 & Braniştea 1 & 45.435608 & 27.835386 \\
\hline 15 & Şendreni & 45.412189 & 27.921098 \\
\hline 16 & Șendreni 1 & 45.411135 & 27.928255 \\
\hline 17 & Movileni & 45.404823 & 27.967254 \\
\hline 18 & Movileni 1 & 45.406661 & 27.966868 \\
\hline 19 & Galați - Barboşi & 45.399934 & 27.987714 \\
\hline 20 & Galați - Fileşti & 45.444416 & 28.008603 \\
\hline
\end{tabular}

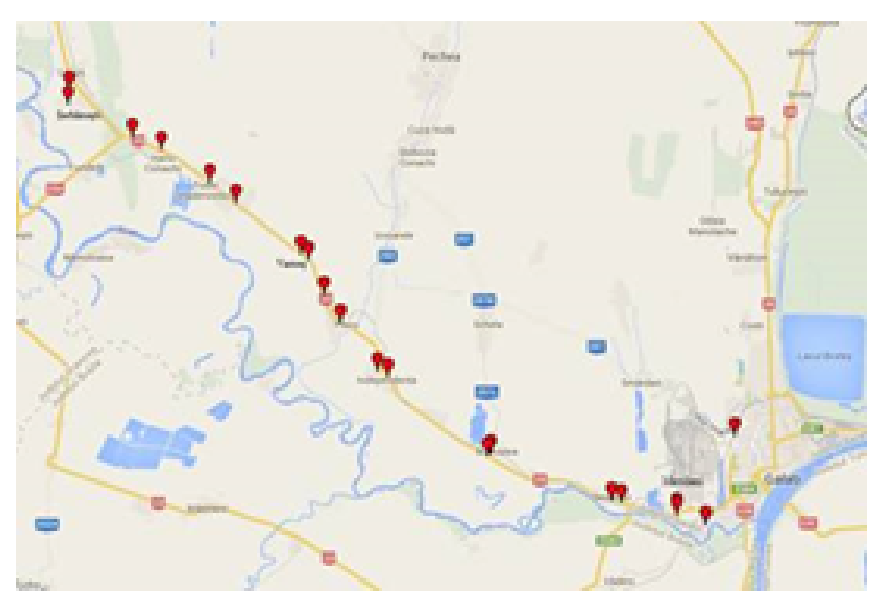

Fig. 1. Sampling points of water probes 
apart from each other. Exception was made for Movileni which lies at a distance of only $400 \mathrm{~m}$ between them. For the Galati City were chosen a well drilled in Barbo-i district and a fountain from Filesti district. It should also be noted that the towns of Movileni, Sendreni, Branistea, Independence, Piscu and Vames have centralized source of drinking water supply.

The water sample was representative and the composition of the water probe wasn't altered through improper use of sampling techniques. All water probes were done manually, according to standardized methods [3].

\section{Parameters method}

The methods of analysis that were used are both chemicals (complexonometry) and instrumentals (electrochemical with specialized sensors) and there are standardized methods $[4,-7]$. The quality indicators that were analyzed, the methods of analysis and the equipment that were used are presented in table 2.

Temperature $-\mathrm{t}\left({ }^{\circ} \mathrm{C}\right), \mathrm{pH}(\mathrm{u} \mathrm{pH})$, potential $-\varepsilon(\mathrm{mV})$, electrical conductivities - $C(\mu \mathrm{s} / \mathrm{cm})$, total dissolved solids - TDS (mg/L), salinity - SAL ( $\mathrm{mg} / \mathrm{L})$, dissolved oxygen - DO $(\mathrm{mg} / \mathrm{L})$, oxygen saturation - Sat $\mathrm{O}_{2}(\%)$, and gas pressure (mbarr) was determined with instrumental standardized methods [4]. Total hardness, and calcium $\left(\mathrm{Ca}^{2+}\right)$ was determined with titrimetric methods $[5,6]$ and magnesium $\left(\mathrm{Mg}^{2+}\right)$ was determined by mathematical equation [7].

Experimental determination of total water hardness principle is based on the ability of $\mathrm{Ca}^{2+}$ and $\mathrm{Mg}^{2+}$ ions to form chelate complexes with EDTA sodium salt, at $p \mathrm{H}=10$, in the present of a specific indicator: Erio - Black T.

Determination of calcium in the water principle is based on the ability of $\mathrm{Ca}^{2+}$ ions to form stable complexes with EDTA sodium salt, at $\mathrm{pH}=12-13$ in the present of a specific indicator: murexid [6].

Table 2

QUALITY INDICATORS AND USED METHODS

\begin{tabular}{|c|c|c|}
\hline Water Quality Indicators & $\begin{array}{l}\text { Methods of analysis } \\
\text { (STAS, SR sau SR ISO) }\end{array}$ & Type of analysis \\
\hline Temperature $\left(\mathrm{T}^{0} \mathrm{C}\right)$ & $\begin{array}{l}\text { SR EN } 1622 \text { 2000. Water quality. Determination of } \\
\text { temperature in water }\end{array}$ & \multirow{7}{*}{ Instrumental } \\
\hline $\mathrm{pH}(\mathrm{u} \mathrm{pH}), \varepsilon(\mathrm{mV})$ & $\begin{array}{l}\text { SR ISO } 10523 / 1997 . \text { Water quality. Determination of } \mathrm{pH} \text { in } \\
\text { water }\end{array}$ & \\
\hline Electrical conductivities - C $(\mu \mathrm{s} / \mathrm{cm})$ & $\begin{array}{l}\text { SR EN 27888/1997. Water quality. Determination of } \\
\text { electrical conductivities in water }\end{array}$ & \\
\hline Total Dissolved Solids - TDS (mg/L) & - & \\
\hline Salinity - SAL (mg/L) & - & \\
\hline $\begin{array}{l}\text { Dissolved oxygen - DO }(\mathrm{mg} / \mathrm{L}) / \\
\text { Oxygen saturation - Sat } \mathrm{O}_{2}(\%)\end{array}$ & $\begin{array}{l}\text { SR ISO } 5814 / 1990 \text {. Water quality. Determination of dissolved } \\
\text { oxygen in water }\end{array}$ & \\
\hline Gas pressure (mbarr) & - & \\
\hline Total hardness ( $\left.{ }^{0} \mathrm{~d}\right)$ & $\begin{array}{l}\text { SR ISO } 6059 / 2008 \text {. Water quality. Determination of total } \\
\text { hardness in water }\end{array}$ & \multirow[b]{2}{*}{ Titrimetric } \\
\hline Calcium $(\mathrm{mg} / \mathrm{L})$ & $\begin{array}{l}\text { SR ISO } 6059 / 2008 \text {. Water quality. Determination of calcium } \\
\text { content in waters (drinking, surface, underground mineral } \\
\text { supply, }\end{array}$ & \\
\hline Magnesium (mg/L) & Mathematical equation & Mathematic \\
\hline
\end{tabular}

Determination of magnesium in the water principle used mathematical calculation and it's based on difference between the amount of reagent used for titration of the amount of cations $\mathrm{Ca}^{2+}$ and $\mathrm{Mg}^{2+}$ and the amount of reagent used for titration of the $\mathrm{Ca}^{2+}[7]$.

\section{Results and discussions}

In order to succeed in reaching a fine representation of the quality of well water in Galati County it was performed sampling of water probes for about 20 well water that represent monitoring points. The water samples were taken and analyzed monthly during a two years' period.

In figure 2 are presented the $\mathrm{pH}$ seasonal variation boxplot for the monitoring points. It could be noted that in all locations, values of higher $\mathrm{pH}$ value are registered in the rainy seasons (spring and autumn) compared to other seasons where rainfall is lower. The variations are in the range of 7.4-8 units and for some locations one can notice a remarkable established throughout the year, being the fountain in Serbanesti. On another hand, during the annual interval there are significant differences between the measured $\mathrm{pH}$ from the same village as the Independena water wells case.

In figure 3 are presented the DO seasonal variation boxplot for the monitoring points. There are registered significant differences between the seasons. The lowest values are recorded during the summer due to the fact that the solubility of oxygen decreases as water temperature increases [3-5]. There are significant differences between the seasons for all sampling points, measured values showing increases of about 10 times during the cold periods (such as the water fountains in 'erbãne'ti or Tudor Vladimirescu).

Figure 4 shows the salinity seasonal variation box-plot for the monitoring points. For a erbãne-til monitoring point and Tudor Vladimirescu monitoring point there are major differences between seasons and between sampling points. This is an aspect that results primarily from the realistic depth of the studied wells.

The TDS seasonal variation box-plot for the monitoring points is showed in figure 5 . During the annual interval there are significant differences between all monitoring points for the measured values of TDS. Also, significant differences can be easily noticed during a seasonal analysis of the recorded data.

The conductivity seasonal variation box-plot for the monitoring points is presented in figure 6 . During the annual interval there are significant differences between monitoring points for the measured conductivity at Serbanesti and from a season to another. For Tudor Vladimirescu monitoring points there are differences between the water conductivity sampled from the two sampling points for autumn and spring seasons. 

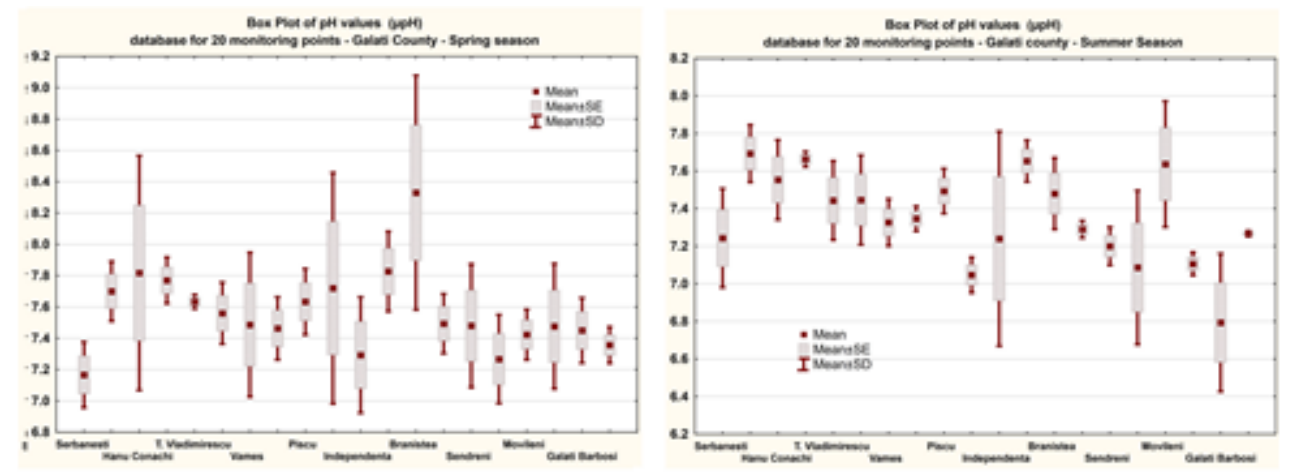

Fig. 2. $p \mathrm{H}$ seasonal

variation box-plot for the monitoring points.
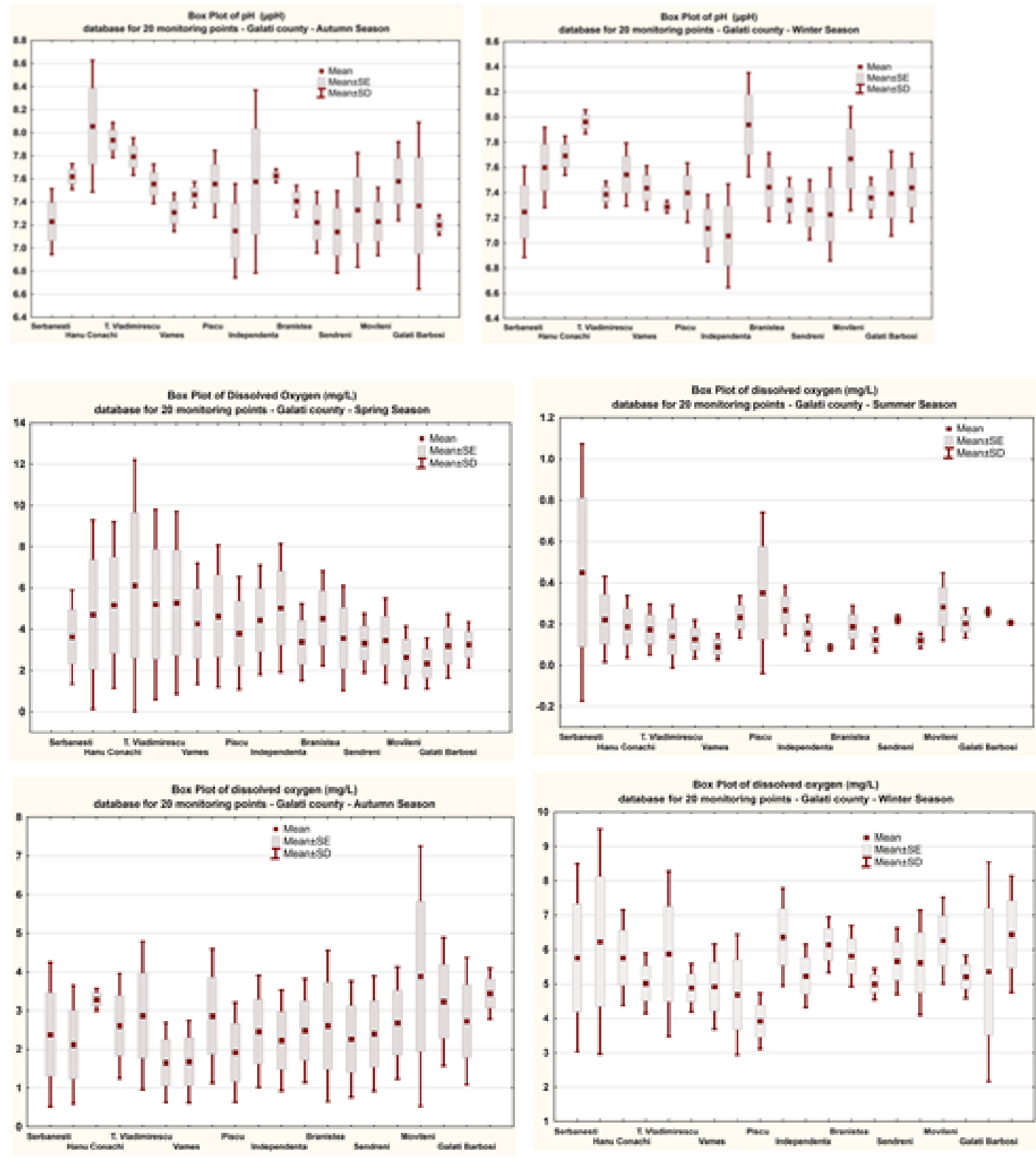

Fig. 3. DO seasonal variation box - plot for the monitoring points.

In figure 7 is presented the total hardness seasonal variation box-plot for the monitoring points. During the annual interval there are differences between seasons for the determined total hardness at Hanu Conachi monitoring points and in spring season between monitoring points. In winter season there are differences between monitoring points at Tudor Vladimirescu.

In figure 8 is presented the calcium seasonal variation box-plot for the monitoring points and in figure 9 are presented the magnesium seasonal variation box-plot.

During the annual interval there are differences between seasons for the determined calcium for all monitoring points. In summer and spring season there are differences between monitoring points at Hanu Conachi. In winter season there are differences between monitoring points at Tudor Vladimirescu.

\section{PCA method approach for specific correlations}

In order to identify the factors that affect the water quality, besides seasonal variation box-plot for each quality indicators, it was made PCA for each monitoring points [8, 9]. Entire statistical analysis was performed using StatSoft STATISTICA 10 (StatSoft, Inc., USA).

For the monitoring points, results of PCA statistical analysis will be presented for the particular case of dependence between $\mathrm{pH}$, calcium concentration and TDS 

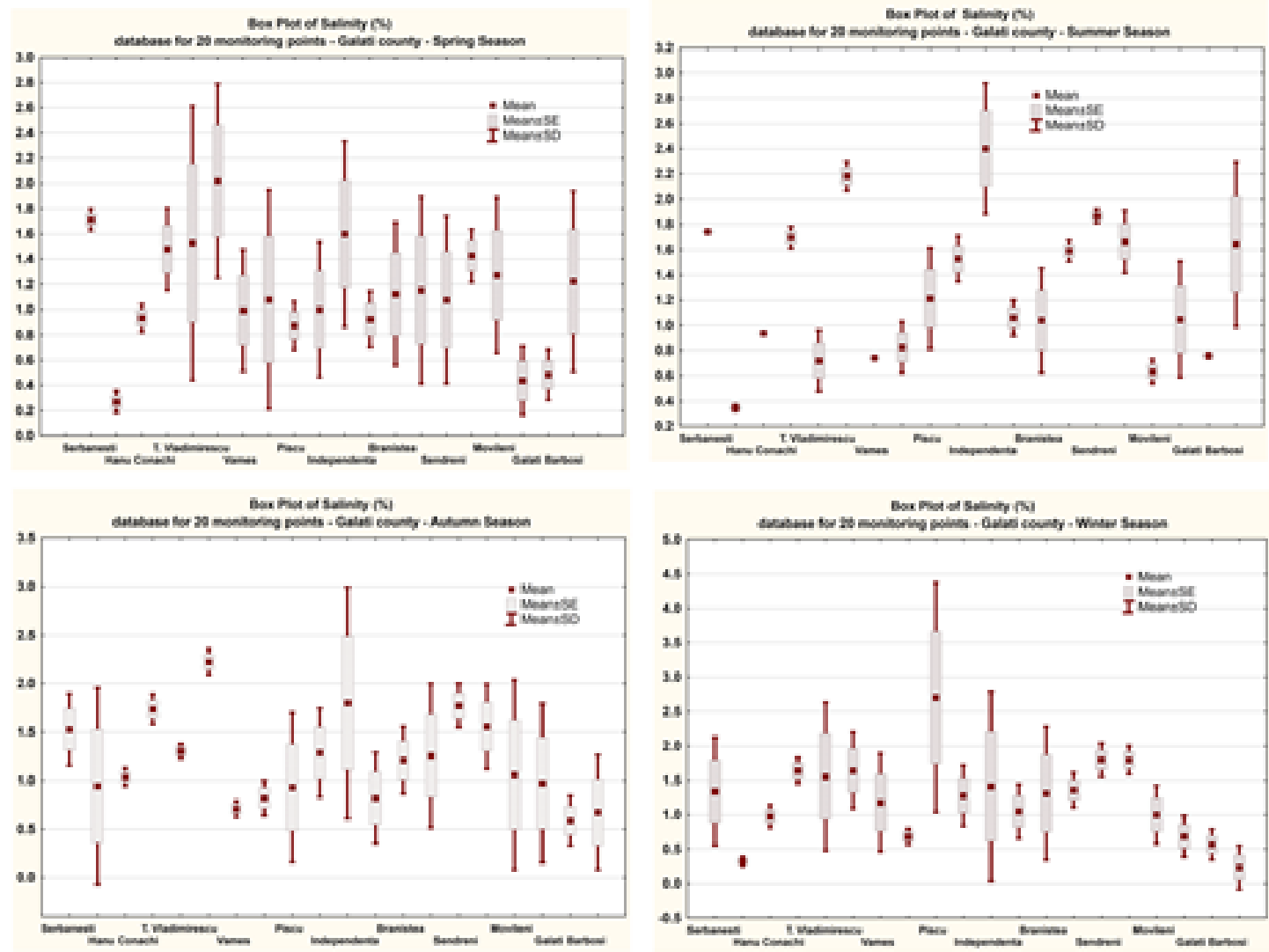

Fig. 4. Salinity seasonal variation box-plot for the monitoring points.
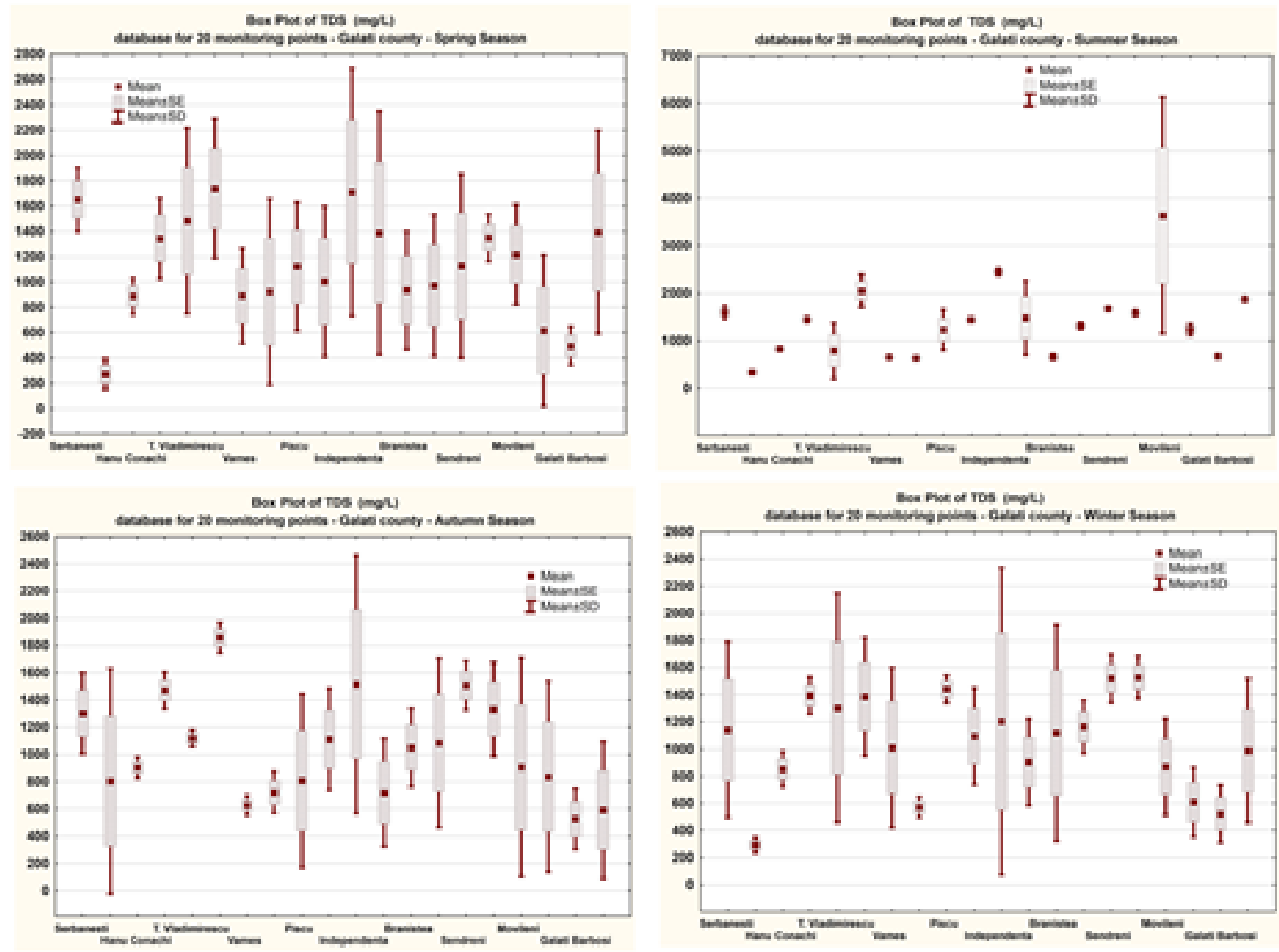

Fig. 5. TDS seasonal variation box-plot for the monitoring points. 

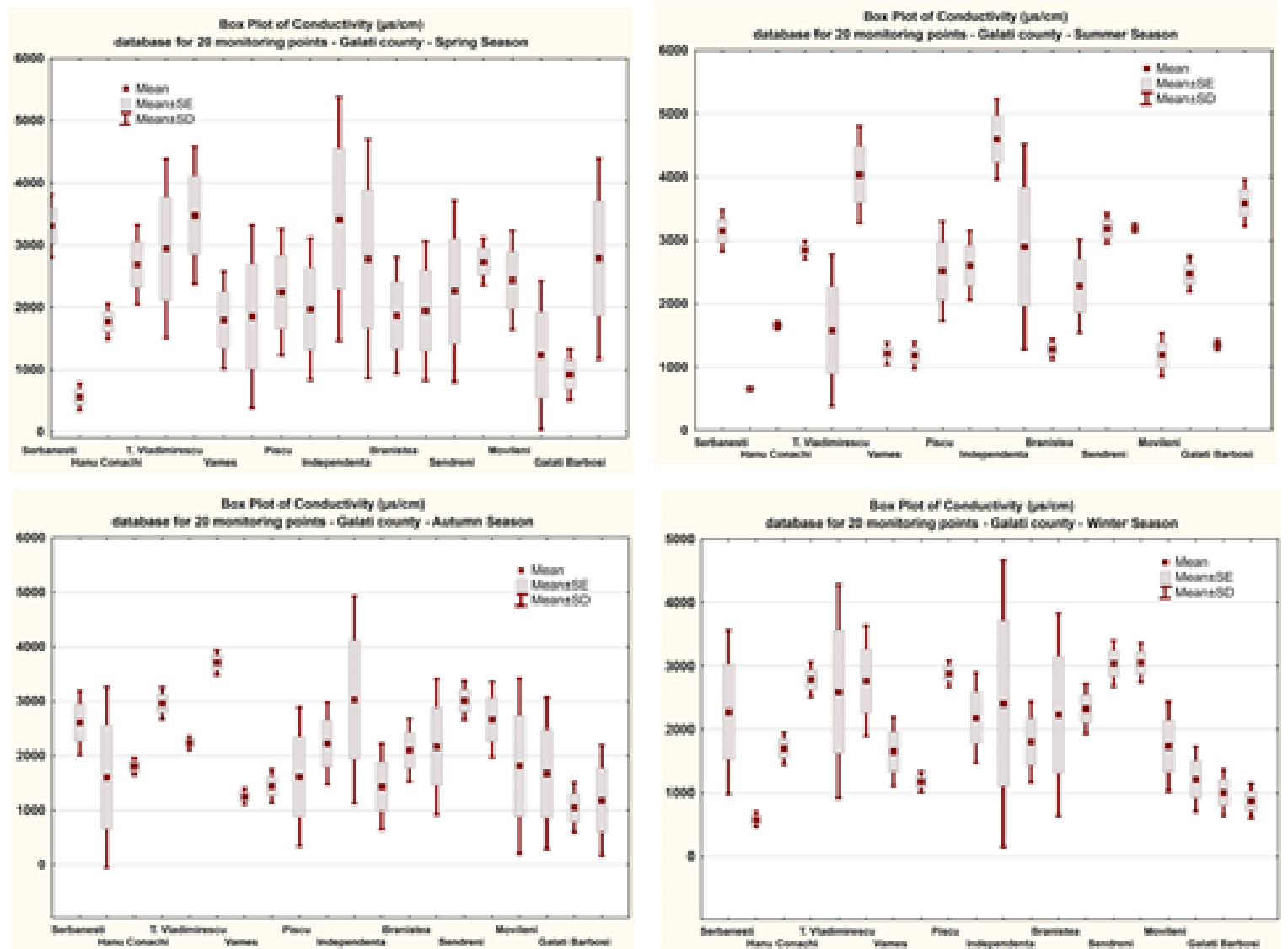

Fig. 6. Conductivity seasonal variation box-plot for the monitoring points.
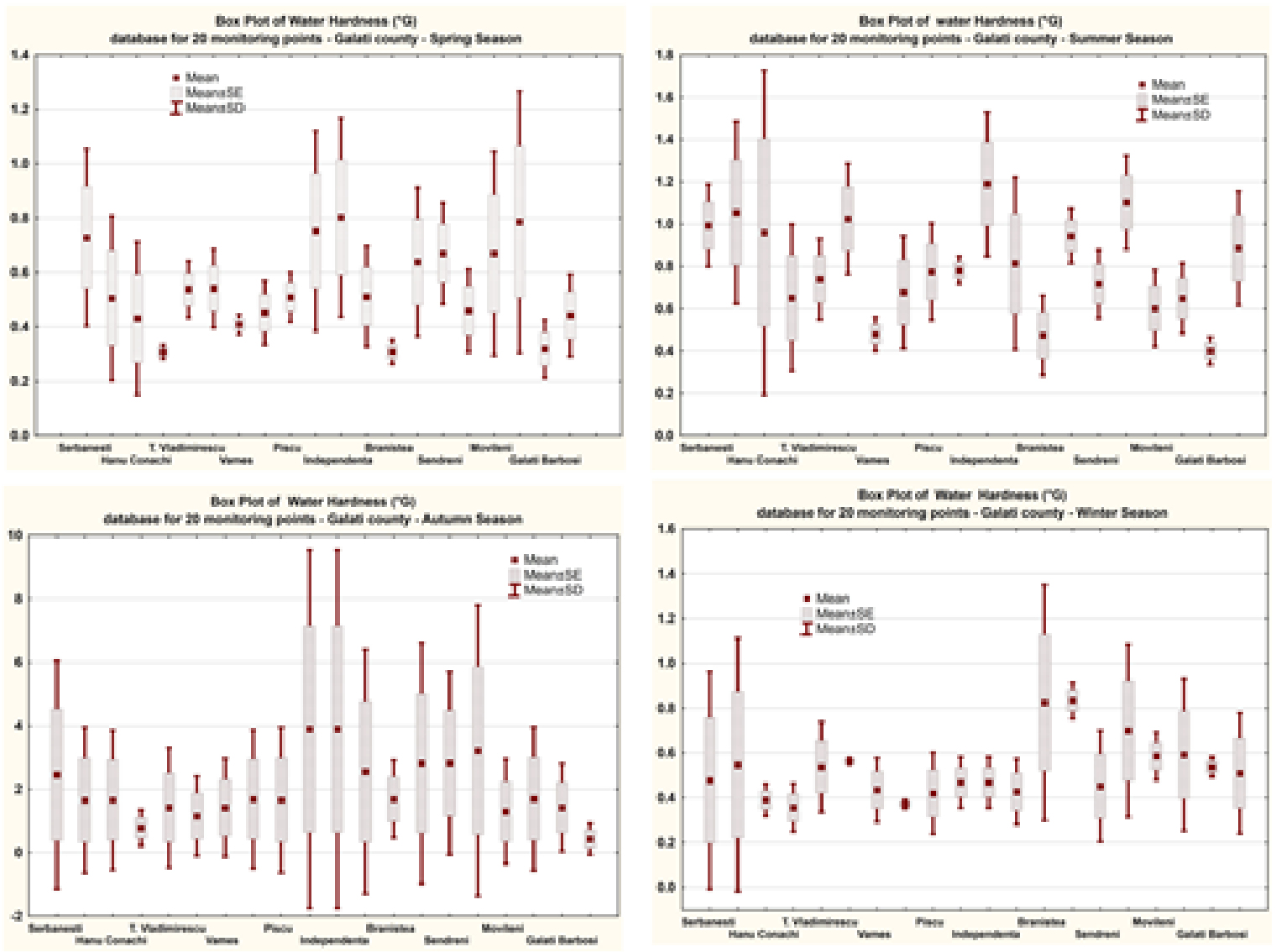

Fig. 7. Water hardness seasonal variation box-plot for the monitoring points. 

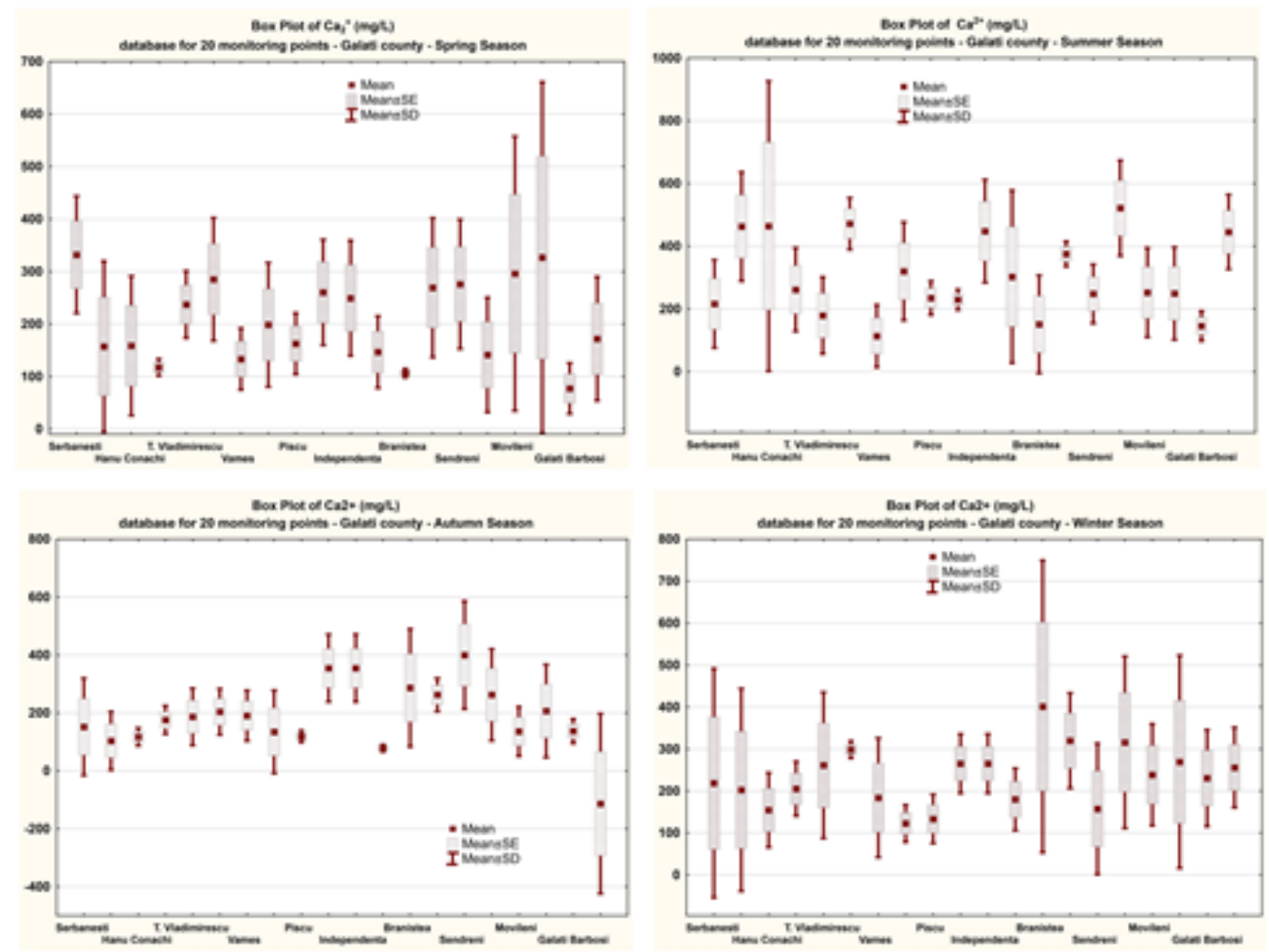

Fig. 8. Calcium seasonal variation box-plot for the monitoring points
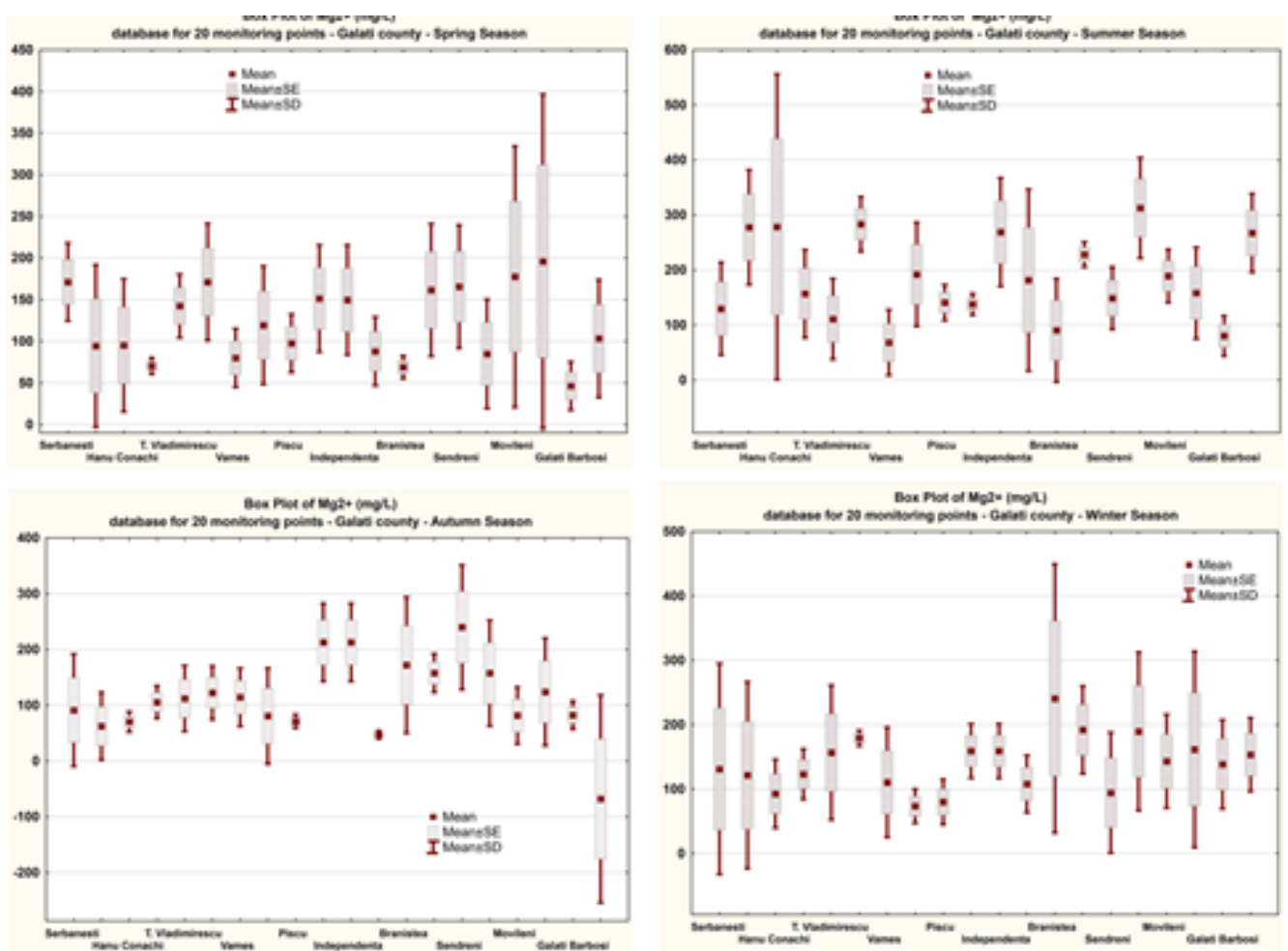

Fig. 9. Magnesium seasonal variation for the monitoring points

respectively. The results that had been obtained are presented in figure 10 to figure 12 .

As it is known, TDS correlates positively with conductivity and affects $\mathrm{pH}$ [7]. The higher TDS and conductivity and lower the $\mathrm{pH}$ towards the acidity $[3,6,7]$. Worldwide, there are no agencies having scientific data to support that drinking water with low TDS will have adverse health effects [7]. Due to the reason, we considered for each monitoring point the dependence between $\mathrm{pH}$, calcium concentration and TDS $[6,7]$.

As it can be seen, fountains that show significant seasonal variations for $\mathrm{pH}$ ( such as Hanu Conachi or Tudor Vladimirescu fountains) show unstable dynamic equilibrium response surfaces with the positioning of representative points in peak areas. For monitoring points showing $\mathrm{pH}$ stability, there are some forms of the stable dynamic balance chart, with the positioning of representative points in minimum areas (for instance the Serbanesti 1 or Vames fountains). Future numerical analysis of chemical equilibrium states will allow the deepening of the internal mechanisms that determine these configurations. A number of important works in this regard have been published [9-12] and our research is under way.

There is a recommendation regarding high TDS, which is to drink water with less than $500 \mathrm{mg} / \mathrm{L}[1,8-10]$. Our 

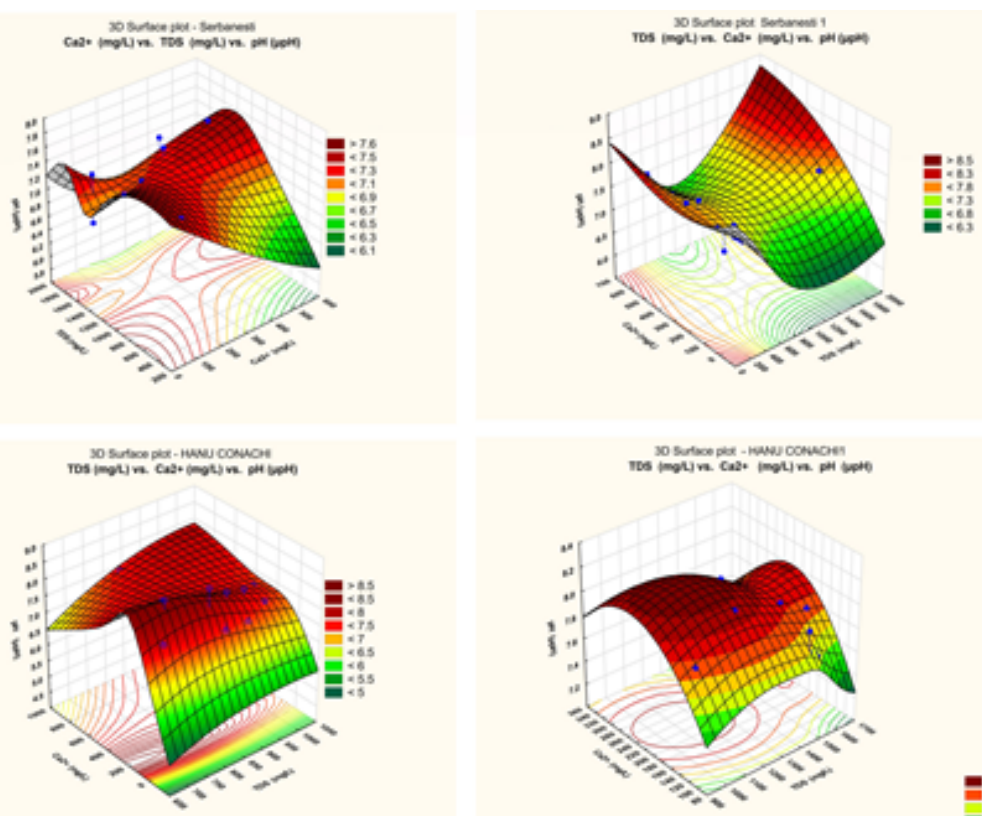

르:",

Fig. 10. Surface plot for $p H$ dependence by calcium concentration and TDS variation for Serbanesti, Serbanesti 1, Hanu Conachi, Hanu Conachi 1, Tudor Vladimirescu, and Tudor Vladimirescu 1 monitoring points
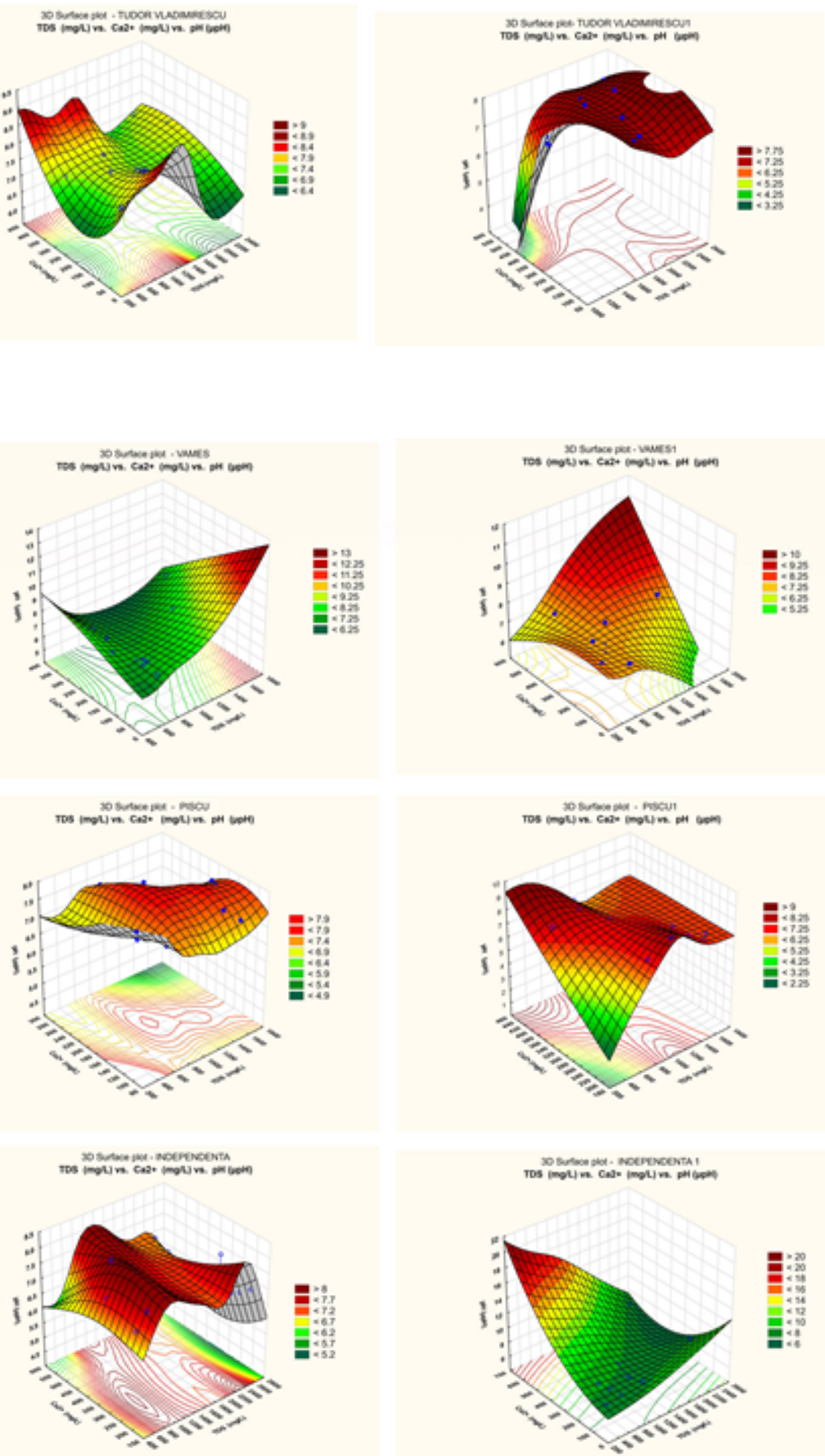

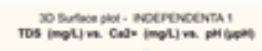

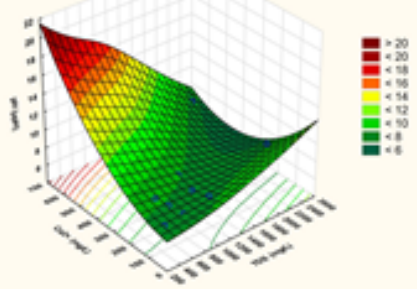

Fig. 11. Surface plot for $\mathrm{pH}$ dependence by calcium concentration and TDS variation, for the second series of monitoring points 

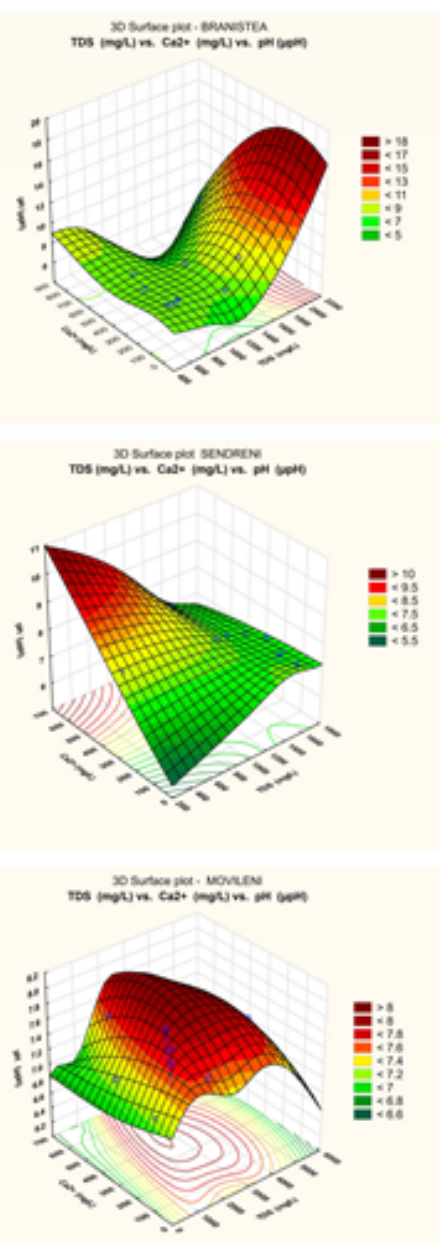

results showed that 1 of 20 annual samples set contained $<500 \mathrm{mg} / \mathrm{L}$, 5 of 20 annual samples set contained $<1000 \mathrm{mg} / \mathrm{L}$, 1 of 20 annual samples set contained $<1500 \mathrm{mg} / \mathrm{L}$ and 3 of 20 annual samples contained $>1500 \mathrm{mg} / \mathrm{L}$ ).

\section{Conclusions}

A plan of monitoring of a series of drilled water well corresponding on a surface of about a quarter of Galati County was started two years ago. The monitoring program was made monthly and covered about 20 monitoring points in order to show a fine representation of the well water quality in this area.

We used both chemicals (complexonometry) and instrumentals (electrochemical with specialized sensors) standardized methods to studies 12 quality indicators for all of 20 monitoring points. Only $10 \%$ of a total of 20 analyzed wells in Galati County over a period of two years proved to have drinkable water. This percentage suggests an alarming urge to inform and educate the public on how to construct and use wells, monitoring water quality from private wells and implement the measures recommended by the World Health Organization [11, 12].

Acknowledgment: This work was carried out in the framework of the Ministry of Research and Innovation project-6PS/2.11. 2017- Research to support the development of capacity to monitor, assess and capitalize on natural resources from wetlands of international importance in Romania and the Black Sea coastal zone.

\section{References}

1. *** Water Quality Monitoring - Best Management Practices for New York state Courses, (2014).

2. FLORESCU, D., IONETE, R.E., SANDRU, C., IORDACHE, A., CULEA, $M$., The Influence of pollution Monitoring Parameters in characterizing
Fig. 12. Surface plot for $p H$ dependence by calcium concentration and TDS variation for the third series of monitoring points the surface water quality from Romania southern area, Rom. Journal of Physics, 5-6 (2011).

3. MEI-LIN WU, YOU-SHAO WANG, CUI-CI SUN, HAILI WANG, JUN-DE DONG, JIAN-PING YIN, SHU-HU HAN, Identification of coastal water quality by statistical analysis methods in Daya Bay, South China Sea., Marine Pollution Bulletin 60, no. 6 (2010): 852-860. http://dx.doi.org/ 10.1016/j.marpolbul.2010.01.007.

4. ASTEL, A., BIZIUK, M., PRZYJAZNY, A., NAMIE氏EIK, J., Chemometrics in monitoring spatial and temporal variations in drinking water quality. Water research 40, no. 8: 1706-16. http:// www.ncbi.nlm.nih.gov/pubmed/16616291 (2006).

5. POPA, P., MURARIU, G., TIMOFTI, M., et. al., Multivariate statistical analyses of Danube River water quality at Galati, Romania, Environmental Engineering And Management J ournal Volume: 17 Issue: 5 Pages: 1249-1266, 2018;

6. TIMOFTI, M., POPA, P., MURARIU, G., et. al., Complementary Approach For Numerical Modelling of Physicochemical Parameters of The Prut River Aquatic System, Journal of Environmental Protection And Ecology,17, 1, 53-63, 2016

7. HODISAN, S., BADEA, G.E., BUNGAU, S., SEBESAN, M., MELINTE (FRUNZULICA), POAP, M., TIT, D.M. The Quality of Underwater Supplies in Western Romania, Rev. Chim. (Bucharest), 69, no. 9, 2018, 23182321

8. COPOLOVICI, L., TIMIS, D., TASCHINA, M., COPOLOVICI, D., CIOCA, G., BUNGAU, S., Rev. Chim. (Bucharest), 68, no. 9, 2017, p. 2076 9. SAMUEL, A.D., TIT, D.M., MELINTE FRUNZULICA, C.E., IOVAN, C., PURZA, L., GITEA, M., BUNGAU, S., Rev. Chim.(Bucharest), 68, no. 10, 2017, p. 2243.

10. ANDOVICl, O., BADEA, G.E., BADEA, T., Rev. Rou. Chim. 48, nr. 8, 2003, p. 591.

11. MOGA, M., PLES, L., BIGIU, N., MANITIU, I., BADEA, M., J. Environ. Prot. Ecol., 12, nr. 3A, 2011, p. 1375

12. GURZAU, A.E., POPOVICl, E., PINTEA, A., POPA, O., POP, C., DUMITRASCU, I., Carpathian J. Earth Environ. Sci., 5, 2010, p. 119. 